\title{
A psychological study of Margaret Drabble's The Red Queen (2004)
}

\author{
Usha Rani Gupta ${ }^{1}$, Sharanpal Singh ${ }^{2}$ \\ ${ }^{1}$ Department of English, Punjabi University, Patiala, INDIA \\ ${ }^{2}$ Department of Distance Education, Punjabi University, Patiala, INDIA
}

\section{Email address:}

ushagupta190785@gmail.com (U. R. Gupta),rajeshateli@gmail.com (S. Singh)

\section{To cite this article:}

Usha Rani Gupta, Sharanpal Singh. A Psychological Study of Margaret Drabble's The Red Queen (2004). International Journal of Literature and Arts. Vol. 2, No. 1, 2014, pp. 24-30. doi: 10.11648/j.ijla.20140201.15

\begin{abstract}
This study is about the psychological problems of women in contemporary society as illustrated in Margaret Drabble's selected novels. Judith Butler's gender and performativity theory will help us to understand psychological problems of women in a better way. Moreover, the postulates of Butler's gender performory help women to come out of their psychological problems. For this purpose, we have selected Drabble's the Red Queen (2004). This study leads us to the conclusion that women are stressed and depressed because of performative norms that are assigned to them by culture and society.
\end{abstract}

Keywords: Judith Butler, Gender, Performativity, Margaret Drabble’s Novels, Psychological Problems

\section{Introduction}

This paper is an attempt to focus on the psychological problems of women characters in Margaret Drabble's The Red Queen (2004) using theoretical inputs of Judith Butler. Drabble dives deep into the inner mind of stressed women and brings to light their issues which are the outcome of gender performative norms embedded in culture. In this novel, we are exclusively concerned with female protagonists who are suffering from the problem of psychological stress in a male-dominated culture and society. To the best of my knowledge, Drabble's novel The Red Queen (2004) has scarcely been studied from the psychological perspective. The postulates of Butler's gender performativity theory help us in understanding Drabble's The Red Queen (2004) from this perspective.

This paper is structured as follows. In section 2, Butler's gender and performativity theory is explained. Section 3 is devoted to how Butler's theory can be successfully applied to Drabble's The Red Queen (2004). Finally, in the last section, we make concluding remarks.

\section{Butler's Gender and Performativity Theory}

Butler's gender theory is probably regarded as her most crucial intervention in the diverse array of academic fields in which she has evinced interest. Being a postmodernist, Butler elicits postmodern concerns of gender in Gender Trouble: Feminism and the Subversion of Identity (1999), Bodies That Matter: On the Discursive Limits of "Sex" (1993), The Psychic Life of Power: Theories in Subjection (1997), Undoing Gender (2004) and others. Butler's most crucial gender concern is that gender is not what one is but is something that one does or performs. Butler is also interestingly concerned with the psychic aspect of identity. In addition, Butler explicates the role of social regulations and power in the formation of the psyche. Gill Jagger in Judith Butler: Sexual Politics, Social Change and the Power of the Performative (2008) says that for Butler, gender identity (masculine and feminine) is the consequence of continued submission to the operation of social and power regulation. These are pertinent for the formation of the psyche and continued existence for the subject who is passionately attached to them and who is really dependent on them for their survival. A woman being a subject is dependent on them for recognition, visibility or place in society. So, women's psyche is restrained by a power structure that is male dominated. This power structure controls women's psyche compelling them to follow their gender stereotypical norms like passiveness, 
politeness, tolerance and sadness. Conversely, men are viewed as more likely to show emotions of a more dominant nature such as anger, boldness, courage, assertiveness, intolerance, activeness and fearlessness. The power structure values masculine traits more highly than feminine ones to establish male superiority. From childhood, boys and girls are trained in appropriate gender specific forms of behaviour, play, dress and so on. For instance- if girls do not like dolls, then they are compelled to play properly. So, these cultural factors play a significant role in determining the psyche of male and female. This training is continuous and mostly subtle, but when necessary can involve punishments for those who do not perform their gender role correctly and properly. Women are bound to follow these traits that are expected of them, willingly or unwillingly. Butler in The Psychic life of Power explicates:

"The desire for desire is exploited in the process of social regulation, for if the terms by which we gain social recognition for ourselves are those by which we are regulated and gain social acceptance" (79).

Furthermore, desire for recognition, visibility and place is also understood in linguistic terms because it is argued that it is only through language that individuals become intelligible as subjects. They become intelligible to the extent that they are first established in language. Gill Jagger in Judith Butler: Sexual Politics, Social Change and the Power of the Performative (2008) says that according to Butler, "the categories through which we give shape to the world are not given in the structure of the mind but are the products of language" (71). Butler in Gender Trouble: Feminism and the Subversion of Identity (1990) also quotes the claim of Monique Wittig who is also concerned with the power of language. Wittig states that "language is an instrument and tool that is misogynist not only in its structure but also in its application" (35). Language misrepresents women. In this way, desire becomes the desire for existence or survival and the way to this is through cultural norms and social regulation that work through the establishment of primary dependencies on power and language.

Moreover, she argues that the concept of masculinity and femininity is established through the loss of certain sexual bonds in the oedipal stage that are not grieved, but are prevented as a possibility from the beginning. Butler in The Psychic Life of Power (1997) explicates that these attainments could be easily grasped in terms of the workings of a heterosexual melancholy:

"The melancholy by which a masculine gender is formed through the refusal to grieve the masculine as a possibility of love; a feminine gender is formed (taken on, assumed) through the incorporative fantasy by which the feminine is excluded as a possible object of love, an exclusion never grieved, but 'preserved' through heightened feminine identification" (146).

So, gendered subjectivity is not one's choice but the result of social regulation. Acting out of social and cultural norms brings ostracism, punishment and violence. Explicitly, the fear of homosexual desire in a woman may induce the panic that she is losing her femininity or she is not a proper woman.

Butler also presents radical views about the concept of power. Gill Jagger in Judith Butler: Sexual Politics, Social Change and the Power of the Performative (2008) comments on Butler's concept of power. Butler states that "the power that is formative of psyche is social in origin and so open to resistance and change" (99). The subject's relationship to power is uncertain as it depends on power for its existence, and yet it also exerts power in unexpected and potentially subversive ways. Butler says, "Power itself possesses an unconscious that provides the conditions for radical reiteration" (128). Butler in The Psychic Life of Power (1997) also explains the premise how subversive acts can be accepted in society through Althusser's example of the policeman. Policeman on the street calling "Hey you there!". Here this performative effort of naming can only attempt to bring its addressee into being. But, there is also the possibility of certain misidentification. So, the one who is called may fail to hear, turn the other way, answer to another name and insist on not being addressed in that way. So imaginary is a sphere that makes recognition possible. Butler also quotes the claim of Jacqueline Rose. According to Butler, Rose claims:

"The unconscious constantly reveals the "failure" of identity. Because there is no continuity of psychic life, so there is no stability of sexual identity, no position for women (or for men) which is ever simply achieved. Nor does psychoanalysis see such "failure" as a special case of inability or an individual deviancy from the norm. "Failure" is not a moment to be regretted in the process of adaptation or development into normality; "failure" is something endlessly repeated and relived moment by moment throughout our individual histories. It appears not only in the symptoms, but also in dreams, in slips of the tongue, and in forms of sexual pleasure which are pushed to the sidelines of the norm . . . there is a resistance to identity at the very heart of psychic life" (97).

In addition, Butler in Excitable speech (1997) says that language has the capacity to enable social existence and also to injure. There is a kind of linguistic vulnerability at the heart of subjectivity. Explicitly, this vulnerability carries within it the possibility of resistance.

The gist of Butler's theory is that women's psyche is restrained by power structure and cultural factors that bind them to follow gender stereotypical norms. These factors play a significant role in causing psychological problems for women. In addition, the postulates of Butler's gender performativity theory help women to deal with their psychological problems. So, there is a need that women should resist those gender stereotypes that have dictated their subordinate condition. They should also feel free to do what they desire or want. They should strive for equality with men. 


\section{Application of Butler's Theory to Drabble's The Red Queen (2004)}

Gender and performativity theory of Butler aids us to understand the complex situation of women in Drabble's The Red Queen (2004). This novel echoes Butlerian thoughts providing numerous instances. Butler's gender and performativity theory is quite complex, but some premises of Butler help us to examine how women are getting stressed and how they are trying to improve their situation. Here, specific attention is focused on female gender that is stressed in a male dominated culture. The most crucial concern of Butler's theory is that women are not getting stressed in male dominated society because they are born as females but they are stressed due to performative norms prevalent in the culture that controls women's psyches. Some postulates of Butler's gender performativity theory also offer solutions for stressful situations of women. So, it is natural to apply Butler's theoretical concepts on the subject to the novel The Red Queen (2004) to analyze women's condition in a male dominated world. With the help of these theoretical concepts, we can better understand Drabble's The Red Queen (2004).

Drabble became famous in the 1960s for her short novels, but now she is listed among powerful, interesting and accomplished postmodern women writers of the twenty-first century. Drabble's early novels of the 1960s were all aphoristic, first-person narratives of young, educated women in conflict with their social and familial situations in the changing society of Britain. From the 1970s, Drabble started to concentrate on social issues of Britain. But now, she is chiefly concerned with women's lives and their problems. In 2004, Drabble published a unique novel with the blending of postmodern and supernatural elements that was unlike any of her previous novels. But in other respects, it occupies its place with all of Drabble's fiction, in the sense of relating women's lives against the social culture and environment. Milada Frankova in The Red Queen: Margaret Drabble's (Auto) Biographical Pastiche (2011) says that Drabble "was compelled by the uncanny power of the autobiographical story and its voice to carry on the message across times and cultures" (81).

Drabble's The Red Queen (2004) provides an insight into the psychological suffering of women characters. The Red Queen (2004) is a complex story, divided into two distinct sections concerning ancient and modern times. In the first section, there is the story of $18^{\text {th }}$ century Korean Crown Princess. Here, Drabble describes the extraordinary life of the Crown Princess, Hyegyong who lives under a tragic regime that has left her a widow and grieving mother. This Princess wants to be remembered. The woman who is selected for this task is Dr. Barbara Halliwell.

The second section is about Dr. Barbara Halliwell. Dr. Halliwell receives an unexpected package, shipped anonymously from an online bookseller. She [reads] the mysterious memoir that is about the Crown Princess. She is deeply intrigued with the Princess because Barbara Halliwell finds her own situation like that of the Princess. In this novel, Drabble has effectively and skilfully mixed postmodern and supernatural elements.

The summary of the novel The Red Queen (2004) reveals that loneliness and frustration in women's lives have been brought about by cultural factors. Supposedly women and men are soul who can establish a harmonious environment and make good sexual chemistry. Then why is their love, honour and identity seized by male-chauvinistic society where women have to suffer from stress, insult, abuse, oppression and injustice. One of the most important factors that is responsible for stress and mental agony is the principles, ideals norms that are constructed by a maledominated culture. Gill Jagger in Judith Butler: Sexual Politics, Social Change and the Power of the Performative (2008) says that Butler explicates the situation. She says:

"Gendered subjectivity is thus achieved and maintained through a primary and continued submission to the (unacknowledged) operations of social power and regulation. These are crucial to the formation of the psyche and the continued existence of the subject who is passionately attached to them and who is indeed dependent on them for 'recognition, visibility, and place'. "(95-96).

This theoretical insight of Butler is evidenced in The Red Queen (2004). In this novel, the $18^{\text {th }}$ century Korean Crown Princess always remains in psychological fear and mental conflict. Before being the Princess, she was only a young girl from a Hong family. She was highly ambitious to wear a red skirt. She says, "I loved it and I fingered it. That skirt spoke to my girlish heart. I wanted one" (3). But, it was her desire for the red skirt that made her life stressful and brought disaster upon her. Her wish was accomplished, "but no good came out of it", and it brought her "no happiness" (4). It also brought worries, tensions, fears and depression. Throughout her life, it was not possible for her to overcome them. In essence, the red skirt proved to be a curse for her.

The institution of marriage also brought fears, tensions and stress instead of bringing joy, happiness and freedom. Marriage between the Princess and the Prince, Sado was really a hardship. After being married to the Prince, it was compulsory for her to follow courtly behaviour. But she was not comfortable in that lifestyle. As she herself explains:

"I was robed in stiff and uncomfortable court clothes of green and violet, and a slave of the bedchamber painted my child's face into an adult mask with unfamiliar cosmetics. I did not recognise myself (15)".

The courtly lifestyle was highly suffocating, but there was no escape possible. As she said:

"I wished to die, and so to avoid my fate. I cannot describe the intensity and the terror of my apprehensions. I felt like a criminal, though I did not know what offence 
I had committed. I cried and cried, and would not be comforted. I was only a child and had not learned the arts of concealment (15-16)".

But her cruel fate moved towards her, "with an army of regulations" and her life was totally like a jail (16). After the consummation of their marriage, Sado took two secondary consorts, by both of whom he sired children. There was nothing unusual in this because it was their custom. She was finding it difficult to accept this custom. She elaborates: "I will not say I did not suffer some jealousy and resentment, for I did, but I did not indulge them inwardly or reveal them outwardly" (56). So, this marital relationship causes the queen to suppress her feelings. She expects to find some solace somewhere.

The Crown Prince and the Princess were married in childhood, but, their marriage was consummated at the age of 15. The Princess was also taught and trained by her mother how to behave in the marital relationship. So, she passively surrendered before her husband as a slave. The queen considered herself a helpless woman because she had to live in a society in which men had the sole power. She passively tolerated everything that was happening with her and around her.

She was also not able to save her husband and her son. Her first Baby Uiso suffered from a weakness of the immune system, and "no cure would have been available" (42). Thus, she was not able to save her first child, Uiso. Then, she gave birth to her second son, Chongjo. But, Chongjo also died. The death of her second child broke her heart. She was quite distressed because she thought herself responsible for her son's death. Under stress, she lamented that "no turf would cover her; no grass would grow over her" (130). This instance draws our attention towards the self-blame resulting from the stressed life of the Princess.

The Prince, Sado was a mad person. His behaviour towards his parents, wife and children was very strange and abnormal. At his $25^{\text {th }}$ birthday, Prince Sado, lost his temper. He abused her parents very badly and also shouted at his young children. His innocent children entered into his room to wish him a happy birthday. But, "he shouted at them to get out, crying out that he knew neither father nor mother, nor son, nor daughters" (87). Seeing this scene, the queen said:

"I felt completely impotent, shrunk to nothingness. I wished to turn to stone, to vanish from this world. Poor children, poor little dolls in their best clothes. What harm had they done to him? They tried so hard to please (87)".

She wanted to save them from her husband's madness, but she was not able to do anything except tolerate what was happening around her.

After the deaths of her husband and son, she lost her status as the Crown Princess. She says: "I have no name, and I have many names. I am a nameless woman. My true name is unknown to history. I am famous, but nameless" (23). "I did not know how to look to the future at this point. No clear path lay before me. I had lost my role and my purpose and my status at court" (128). So these instances imply that the queen's life was full of grief, fear and mental agony. She was not able to overcome them till her death. But nobody asked her how she survived these years. They were so stressful that it was better to die than to live. She states:

But I managed to live long, in such turbulent times. But how could I have allowed myself to die earlier? Many times I wished to die, and sometimes I thought it my duty to die. But in universal terms, in human terms, it was my duty to live. My life was needed. My son and my grandson needed me. I could not abandon them. I survived for them (5-6).

So, in the novel, the Crown Princess is observed as an unhappy woman who assumes the traditional role of a submissive wife silently living her life without raising questions and without having room for indulging and discharging her suppressed feelings.

This novel also presents the psychological study of the modern female character. Dr. Barbara Halliwell is also stressed and mentally upset like the $18^{\text {th }}$ century Korean Crown Princess, Hyegyong. Her husband, Peter Halliwell, had never forgiven Barbara Halliwell for the death of their son, Benedict. "He had seized her by the throat and yelled at her that she was a murderer" (196). She tolerated passively without challenging her husband. "She had forgiven him for it because he was mad" (196). So, Peter Halliwell and Benedict Halliwell are a part of Barbara Halliwell's tragic life. They always hovered in her unconscious mind. The author describes her thoughts:

She has tried so hard to rationalize and to control and to conceal the melodrama of her life, but nonetheless, from time to time, it swoops over her and possesses her. She despises it. She does not wish to live hysterically (307).

When Barbara Halliwell goes to see Korean babies with Ian Van Jost, she is greatly touched at the sight of those babies. Those babies reminded her of her dead son, Benedict. "She is a human being and was once a mother, and the sight of these babies cannot fail to touch her" (257). She was not able to separate herself from her past memories.

After visiting Seoul, she finds it difficult to adjust in her normal routine. Many incidents and sights are hovering in her unconscious mind. Because of those memories, she is mentally upset:

"She dreams of the Chinese baby, waiting in vain for Ian van Jost to come for her. She dreams of van Jost, lying dead in her arms, and the coffin of her prince, listening to the punishment of thunder. She feels she is lapsing into solitude and eccentricity. Her future is opaque. She has lost a clear trajectory. She is in the early prime of her life, but she sees the mocking ghost of her ageing self, beckoning to her across the ravine" (309).

So, Barbara Halliwell is also portrayed as an unhappy woman. This cultural and social regulation compels her to behave appropriately and accurately according to 
established norms that are expected of her.

But now a change is coming in the women's psyches. They are trying to improve their situation undermining their gender stereotypes because they have understood that their stressful situation is due to following these gender stereotypical norms that are assigned to them by power, culture and society that favours the male. Simone de Beauvior in The Second Sex (1984) says that women must try to change their situation. She says that the modern woman wants to be active in several spheres like man. The modern woman calls herself their equal. Butler's gender performativity theory also helps women in providing favourable conditions to improve their stressful condition. Gill Jagger in Judith Butler: Sexual Politics, Social Change and the Power of the Performative (2008) says that according to Butler, social power and regulations are in the operation and formation of the psyche, which also allows for "the possibility of resistance" (89). She elaborates: "This psychic regulation is social and historical and therefore contingent. This allows the possibility for change and transformation" (89).

These theoretical insights are also iterated in Drabble's The Red Queen (2004). Barbara Halliwell is a successful career oriented woman. She has the freedom of a choice that "she has enjoyed in her forty-two years would have been unimaginable to the Crown Princess or to any of the Crown Princess's female contemporaries" (173). In spite of being married, she enjoyed her sexuality according to her own desire. She was free to play with the idea of a dalliance with Robert Treborough. She had enjoyed many sexual relationships in her time. As, she had "a healthy sexual appetite, an appetite condoned and indeed encouraged by late twentieth-century Western culture" (173).

Now women have understood that the role of motherhood has tormented them. Barbara Halliwell herself struggled to save her first son, Benedict, but could not. Then she opined that "she does not think that a woman has a right to a baby" (253). Women can also survive without a child. Barbara explains: "She does not think she will ever attempt to have another baby" as she had led a full life without a child after losing her darling child, Benedict (253).

Even in the memoir of the Crown Princess, we see the Princess undermining gender stereotypes, to some extent. In $18^{\text {th }}$ century Korea, learning was not freely available to women, it was chiefly available to men. The Princess says "learning was not forbidden to women, but nor was it freely offered to them" (33). She was very eager to get learning. So, learning came to her as a gift or surprise. She informs:

I stole learning from my clever young aunt, who was willing to teach me. I stole from Prince Sado, who in those early years was willing to talk to me about history and about literature and about the Confucian texts. I was an eager and a secret scholar (32-33).

Here, the Princess tried to challenge her gender stereotypical role and became a source of inspiration for other women.

\section{Conclusion}

Thus, the novel The Red Queen (2004) presents the complex case of women's stressful situation and also presents a few cases of how women's psyche is changing and that is helping them to improve their situation. Butler's theoretical insights help to understand women's condition from this point of few. The portrayal of women characters in The Red Queen (2004) stresses on this premise that women are to be liberated not only from men but also from their own psychological fears, worries and enslavement. Butler's theory leads us to the conclusion that women's stressful situation is due to secondary roles and performative norms that are assigned to them by culture. This paper makes us familiar with the stress factors that are responsible for women's stressful situation in general and in this novel in particular. This work is important for those who are interested in women's studies and their slow journey to struggle for equality and egalitarianism.

\section{References}

[1] Butler, Judith. Excitable Speech: A Politics of the Performative. New York: Routledge, 1997. Print.

[2] ---. Bodies That Matter: On the Discursive Limits of "Sex". New York: Routledge, 1993.

[3] ---. The Psychic Life of Power: Theories in Subjection. California: Stanford University Press, 1997. Print.

[4] ---. Gender Trouble: Feminism and the Subversion of Identity. 1990. New York: Routledge, 1999. Print.

[5] ---. Undoing Gender. New York: Routledge, 2004.

[6] De Beauvoir, Simone. The Second Sex. Trans. H.M. Parshley. Harmondsworth: Penguin, 1984. Print.

[7] Drabble, Margaret. The Red Queen. London: Viking, 2004. Print.

[8] Frankova, Milada. "The Red Queen: Margaret Drabble's (Auto) Biographical Pastiche". Brno Studies in English, 37. 2 (2011):79-86. Print.

[9] Jagger, Gill. Judith Butler: Sexual Politics, Social Change and the Power of the Performative. New York: Routledge, 2008. Print.

[10] Lipps. H. M. Women, Men and Power. CA: Mayfield, 1991. Print. 